\title{
TRAGEDIA, FILOSOFÍA Y POLÍTICA EN ESQUILO
}

\author{
CÉSAR GARCÍA ÁLVAREZ \\ Universidad San Sebastián. Chile
}

Resumen: El tema que el profesor García desarrolla en esta investigación es Tragedia, filosofía y política en Esquilo; aunque el análisis literario se centra principalmente en la tragedia Prometeo encadenado, el marco teórico referido a la filosofía y política en Esquilo es válido para entender otras tragedias. La línea conductora de esta tesis se encuentra en descubrir y documentar un pólemos en la cultura griega, particularmente evidente en el pensamiento de los presocráticos, y más clara aún en la política ateniense desde Solón, pasando por Pisístrato, Cimón, Clístenes y Efialtes, hasta llegar a Pericles, en quien el pólemos se resuelve en dike.

Palabras clave: Tragedia - Pólemos - Prometeo encadenado Democracia- Política y tragedia - Esquilo.

\section{TRAGEDY, PHILOSOPHY AND POLITICS IN AESCHYLUS}

Abstract: The theme of this investigation is Tragedy, philosophy and politics in Aeschylus. Although the literary analysis is mainly focused on the tragedy Prometheus unbound, the theoretical framework related to philosophy and politics in Aeschylus is valid to understand other tragedies. The guiding line of this thesis is discovering and documenting a polemos in Greek culture, particularly evident in the thought of the Pre-Socratics, and even more clearly in Athenian politics from Solon, through Peisistratos, Cimon, Cleistenes and Ephialtes, until Pericles, with whom polemos is solved into dike.

Key words: Tragedy - Polemos - Prometheus unbound Democracy- Politics and tragedy - Aeschylus.

Recibido: 18.08.15 - Aceptado: 29.09.15

Correspondencia: César García Álvarez

Email: bizantinoscesar@gmail.com

Doctor en Filosofía con mención en Literatura.

Tel. (56-2) 222693878 - 222392292 
$\mathrm{M}$ uchos estudios se han publicado sobre la obra de Esquilo (528 o 524456) ${ }^{1}$ y muchos más seguramente aparecerán. Las obras clásicas, si son clásicas, es precisamente por esto, por lo permanente e inagotable de sus temas ${ }^{2}$.

En la obra de Esquilo confluyen tres grandes temas firmemente interrelacionados: El literario-mítico, el filosófico y el político. Tres temas que

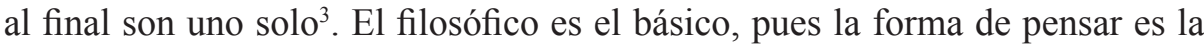
forma del decir (la tragedia como literatura) y del hacer (política). Este es el tema del presente trabajo.

Se han referido a este tema, aunque más como alusión que como detención: Carlos Miralles (Tragedia y Política en Esquilo. Ariel. Barcelona, 1968), Gilbert Murray (Esquilo, el creador de la tragedia, Espasa CalpeAustral, Buenos Aires, 1943), Francisco Rodríguez Adrados (Ilustración y política en la Grecia Clásica. Rev. Occidente, Madrid, 1966) y han aludido al tema otros estudiosos como el de C.D.N. Costa; J.A. Davison; H.D.F. Kitto; A. J. Podlecki; F.Schachermeyr y F. Stoessl.

Este estudio se dividirá en tres partes.

Primera: La filosofía como oposición de contrarios ${ }^{4}$. Aquí examinaremos el

1 Según Vida, biografía anónima que consta en el códice Laurenziano M; así mismo en el Marmor Parium, bastante fiel en materia cronológica. Estos datos biográficos y otros sobre Esquilo, están sometidos a crítica por A.J. Podlecki, The Political Background of Aeschylean Tragedy, Ann. Arbor, 1966, pp.1-7.

2 José Luis de Miguel Jover, solo a modo de ejemplo, en su edición de Akal registra 170 fichas de estudios, que, como él llama, son solo estudios básicos sobre Esquilo.

3 Dejo de lado el tema "barroco" en Esquilo, su multitematismo, cuya fórmula es: "expluribus, unum". Adrados traduce los coros de Prometeo, al modo del Góngora de las Soledades.

4 La totalidad de la vida para los griegos debe ser vista como una contienda agonal. Tejera, Nietzsche and Greek Thought, Dordrecht, Martinus Nijhoff Publishers, 1987, p. 45. No es necesario abundar sobre el término pólemos, sobre el cual existe consenso, sí sobre precisiones al término, tal como es visto por Nietzsche, por Freud u otros intérpretes; véase: "Eros y pólemos en la cultura y la sociedad griegas" de Juan Antonio Roche Cárcel, en Sociedades, civilizaciones y culturas mediterráneas o la investigación de José García Roca Pólemos y stasis en la lírica griega. Universidad 
pensamiento de los presocráticos en cuanto mentalidad presente en la época de Esquilo.

Segunda: La política entendida como un juego de oposiciones hacia la democracia. Convendrá examinar aquí las circunstancias políticas de Esquilo, que concluirán con la democracia de Pericles Tercera: La lectura de la tragedia "Prometeo" de Esquilo en clave filosófico - política. Estudiaremos la estructura de la obra como un proceso que se extiende desde la máxima oposición (Zeus frente a Prometeo, en Prometeo encadenado) a Prometeo liberado, cuya proyección última será la Orestía, obra en las que, al final en las Euménides se instala ya la dike $e^{5}$ la sofrosine, en términos políticos la democracia.

Algo sobre el texto griego que vamos a usar y su traducción. Hemos elegido la traducción de Manuel Férnandez-Galiano. Esquilo. Tragedias Completas. Madrid. Planeta, 1993, no solo por la autoridad de tan destacado helenista, sino, además, por ser una versión poetizada y conveniente enumerada en estrofas y versos, así como anotada ${ }^{6}$.

de Valencia (España).

5 Adelantemos que, de los tres trágicos, es Esquilo quien centra sus obras en las ideas de pólemos y díke. La obra de Esquilo se estructura sobre estas dos palabras: el mundo va del pólemos -su corazón malsano es la hybris - a la sanación que se encuentra en la Díke, hijas de Zeus y Themis.

6 Convendrá decir algo sobre el texto griego que usamos y su traducción. Hemos tenido en nuestras manos varias traducciones: La de Francisco Rodríguez Adrados: Esquilo. Tragedias. Madrid. Biblioteca Clásica Hernando, 1966. Versión en prosa; los coros se encuentran bellamente poetizados. No enumera las estrofas.- La de José Alemany. Esquilo. Tragedias Completas. Madrid. Biblioteca Edaf, 1989. Una versión solo en prosa; como en el caso anterior, sin numeración de estrofas y versos.-La de Juan Salas. Esquilo. Santiago de Chile. Imprenta Cervantes, 1904. Publicado por la Universidad de Chile. Edición en verso y estrofas convenientemente enumeradas. Sigue siendo una de las traducciones más autorizadas.-Fernando Brieva Salvatierra. Esquilo. Editorial Losada, Buenos Aires, Argentina, 1968. Una traducción en prosa, no es bilingüe, pero va acompañada de interesantes notas. Salvatierra informa además sobre códices, ediciones y escolios- Enrique Ángel Ramos Jurado. Esquilo. Alianza Editorial. Edición en verso, con estrofas enumeradas y notas, 2001.-Marcelino Menéndez y Pelayo. Prometeo encadenado. Editorial: Wikisource. La obra es de 1878, traducción hecha a sugerencia de Juan Valera. Está versificada; no obstante, carezca de anotaciones, y numeración de estrofas.

Consultamos también las traducciones de J. Alsina, J. L. Calvo Martínez, M. García 


\section{1.- La filosofía griega como oposición de contrarios}

El término pólemos es un de las palabras más arraigadas en el pensamiento griego de todos los tiempos. Esquilo no fue ajeno a ese concepto ${ }^{7}$; pensemos que Esquilo fue uno de las personas más cultas de la época ${ }^{8}$ y con fuerte compromiso social ${ }^{9}$. Las ideas rectoras de las obras de Esquilo son precisamente: la idea de justicia universal o la dike ${ }^{10}$, la sofrosine frente a la hybris, el difícil proceso (pólemos) para alcanzar los ideales anteriores y la conjunción de los dioses y los hombres en la consecución de tales ideales. En este marco vamos a estudiar sus obras, particularmente Prometeo encadenado. Recordemos lo dicho en la nota dos: El pensamiento griego en sus diversas épocas y variantes, está animado por el pólemos.

Valdés, J. Pali Bonet y B. Perea Morales, en castellano; las ediciones bilingües francesas de Garnier y Belles-Letres; así mismo, las ediciones comentadas de Oxford, en manos de J.D. Denniston - D. Page (Agamenon), la de E. Fraenkel (Agamenon), y la de A.F. Garvie (Coéforas).

7 Terminología que, por lo general, corresponde al campo semántico; tal sucede en Prometeo encadenado; toda la obra es un pólemos entre Zeus y Prometeo, pero Esquilo no la pronuncia la palabra ni una sola vez, sí consigna términos como:

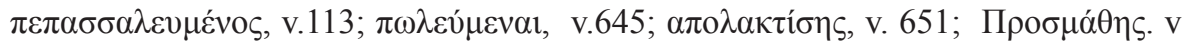
697.

No nos extrañe esta omisión, en Grecia no existió estatua o culto a Pólemos. Quien más personifica a pólemos en sus obras es Aristófanes en Los Acarnienses, La Paz, puede verse: Richard F. Moorton, Jr., «Dionysus or Polemos? The Double Message of Aristophanes' Acharnians,» en The Eye Expanded: Life and the Arts in GrecoRoman Antiquity (University of California Press, 1999), pp. 24, 39, 42, 45.

8 Su padre, Euforión, de la clase Eupátrida (noble) y terrateniente de Eleusis, (Pausanias I.21.2) pudo darle la mejor educación de la época. Conocía a perfección a Homero, Hesíodo, base de sus tragedias, la poesía de Arquíloco, Alceo y Estesícoro, presente éste último en la Orestía; con seguridad conoció personalmente a Anacreonte y Simónides, invitados a Atenas por Hiparco; fue amigo de Píndaro (Eustacio, Proem. Comm.Pind.25). El mismo Esquilo componía la música para sus tragedias, influido por el gran Laso de Hermíone, destacado compositor. Leer a Esquilo, nos ahorra toda ponderación cultural del trágico

9 La infancia de Esquilo se corresponde con la tiranía de los Pisistrátidas, Hipias e Hiparco.

10 La dike o justicia es la idea rectora de la paideia griega hasta finales de la época clásica. Véase Héctor García Cataldo "Díke y hibrys en contrapunto en la poética de Solón”, Universidad Viña del Mar y B. Deforge. Eschile poète cosmique. París, 1986. 
Será necesario dentro de este capítulo sobre la oposición de los contrarios, presentar un brevísimo recuento de la tradicional mentalidad griega, a la luz de los presocráticos, pues Cicerón dirá: "Aeschylus non poeta solum, sed etiam Pythagoreus", término este último que significa "filósofo", más en concreto, platónico ${ }^{11}$.

Ciertamente, Esquilo recoge de Hesíodo ${ }^{12}$ toda la fuerza de la palabra pólemos. Hesíodo (siglo VIII a.C.) no es presocrático, pero está considerado como el primer filósofo por preguntarse en la Teogonía sobre la naturaleza y el sentido interno de sus fuerzas, entre ellas la justicia cuyo camino hacia el orden no es gratuito: "El sendero hacia la virtud es un camino dificultoso, pues requiere un esfuerzo constante y voluntario". Los pólemos de sus dioses o theomaquia-Urano, Cronos, Zeus- que se replica con Prometeo, significan en él ese esfuerzo "constante y voluntario" hacia la justicia, la verdad y, también en términos políticos, la democracia ${ }^{13}$. Nada más evidente en Hesíodo que el tránsito -nada fácil- de un universo desordenado que apetece lo ordenado o sometido a la dike.

En Anaximandro de Mileto los contrarios están siempre en guerra en búsqueda de ciertas estabilidades, algo que ejemplifica con la lucha del frío contra el calor, estabilizándose provisionalmente en el invierno que cede luego por pólemos al verano, con su estabilidad también provisional. Lo consigna así

11 Los presocráticos actúan en Esquilo como tradición del pensamiento griego, y están en él en forma directa: Anaxágoras, Empédocles, Pitágoras, Parménides (Agamenón 788-789) y Jenofonte. En el caso de Pitágoras, es necesaria una aclaración: la crítica ha variado, pasó de un Esquilo rigurosamente pitagórico (Agamenón 76 ss.: Coef., 319; Eum.528 y 657 ss), a un Esquilo familiarizado con todas las teorías filosóficas, sin que opte por ninguna especial. En el caso de Empédocles, Esquilo hace referencia al cuádruple elemento compositivo de la naturaleza: tierra, agua, fuego aire (Coéf.585 ss.; Eum.904 y en Prom. Encadenado Cáucaso (tierra) Oceánidas (agua) el fuego robado y la invocación final al Éter. La vinculación con Empédocles se deduce por el hecho que habla de cuatro elementos, mientras que Pitágoras y Jenófanes solo de tres. Pero los elementos compositivos de la naturaleza estaba en la mentalidad de la época, Esquilo bien pudo inspirarse en esta cultura generalizada. Esquilo escribiría en clave de su tiempo.

12 F. Solmsen. Hesiod and Aeschylus. Nueva York, 1949.

13 W. Jaeger. Alabanza de la Ley: Los orígenes de la filosofía del derecho y los griegos (Trad. A. Truyol y Serra). Centro de Estudios Constitucionales, Madrid, 1982. 


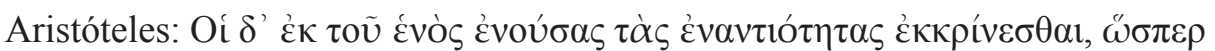

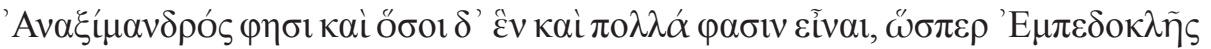

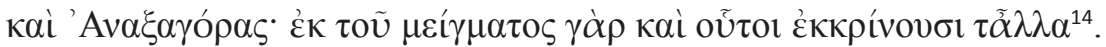

Pitágoras reedita la lucha de los contrarios solo que, ahora, apoyado por el orfismo, esos contrarios son el alma y el cuerpo; el alma ha de luchar contra el cuerpo más allá de la muerte, hasta que tras las purificaciones transmigratorias alcance la armonía en la divinidad.

Empédocles instala en la naturaleza dos fuerzas antagónicas amor y odio, $\varphi \imath \lambda i ́ \alpha$ y veĩkos que buscan, como en el caso de Anaximandro, estados provisionales de armonía, así en el Fragmento 17, versos 1-20) $)^{15}$.

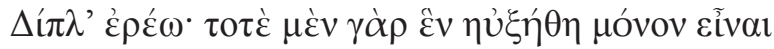

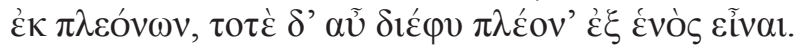

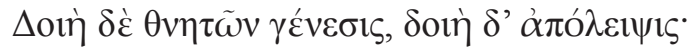

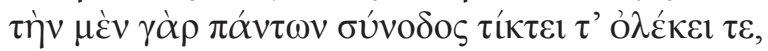

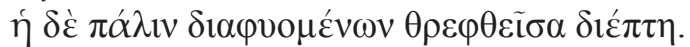

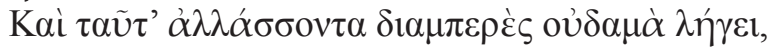

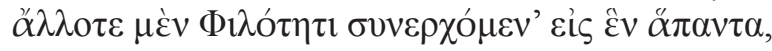

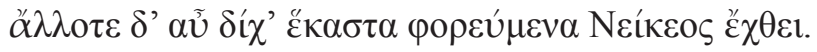

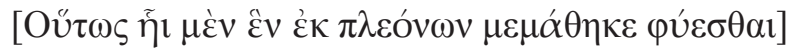

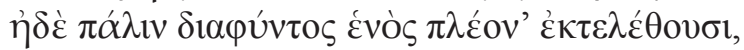

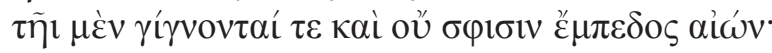

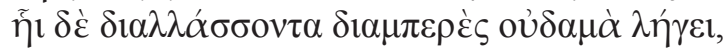

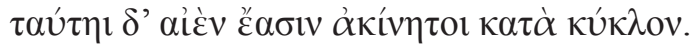

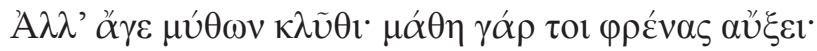

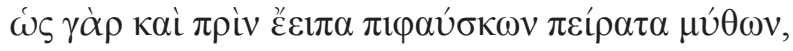

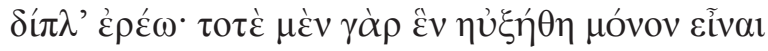

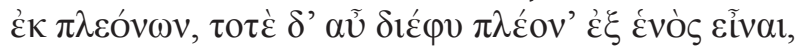

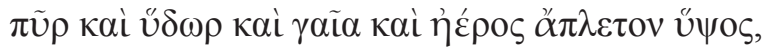

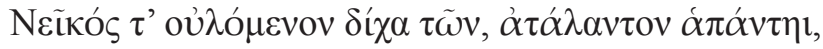

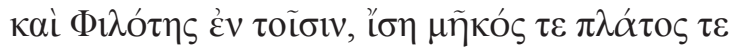

14 (DK 12 A 16) Aristóteles, Fís. A4, 187 a 20.

15 Empédocles: (DK 31 B 17). 
Anaxágoras entiende que en todo ser existen semillas de lo demás, lo que motiva el pólemos. El Estagirita se refiere a él en estos términos ${ }^{16}$ : Oí $\delta$ ' $̇ \kappa$

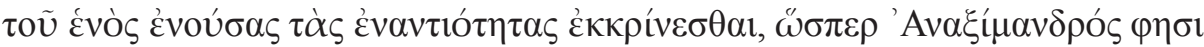

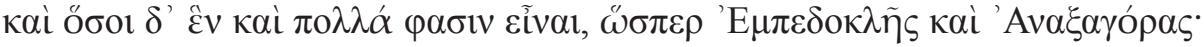

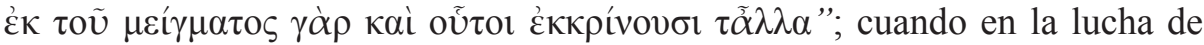
elementos predomina uno sobre el otro, se establece una armonía provisoria: si la hierba se convierte en carne en la vaca que la come, es porque en la hierba existe algo ya de carne, que establece en el animal una pausa vital, hasta que la tierra, que existe también en la vaca, hace que su cuerpo se convierta en tierra.

Demócrito ama el pólemos, pero lo sitúa en los átomos, aunque éstos sean ajenos a la dike; el azar es quien genera el movimiento sin que tengamos que apelar a estados de armonía.

Un día estudiaba yo a Heráclito, su pólemos de lucha de contrarios, durante largas horas de la noche, particularmente el frg. 96. Un sueño me aclaró el problema: "Había domesticado a seres extraños, monstruosos tal vez provocado por unos disfrazados que vi el mismo día en la Plaza de Armas- monstruos que en sueños logré domesticar; poco después vi que por un doble túnel algunos de esos monstruos, supuestamente domesticados, corrían desaforados: unos por una galería subterránea y otros por otra (señalaré que había visto esa noche el rescate de los 33, su solidaridad allá abajo, su disensión a veces). Expliqué entonces a un amigo, también en sueños, que ello era incomprensible, si yo había adoctrinado a los monstruos y estaban en concordia. El susodicho amigo, que era Heráclito, me respondió: Ven conmigo, yo solucionaré el problema, pues el mundo ama la paz; vi cómo él reunió a ambos bandos de monstruos, los colocó en forma circular, con una breve separación entre ambos, eran dos segmentos circulares, casi pegados, y les predicó el fragmento 96: "El Ser-que es Dios, Mundo, Hombre-es día y noche, invierno y verano, guerra y paz, hambre y saciedad; pero, él, toma diversas formas, como el fuego, que al mezclarse con distintas inciensos, toma el olor de cada uno"; los monstruos se fueron pensando y devino la paz.

El sueño me hizo comprender el pensamiento de Heráclito.

16 (DK 12 A 16) Aristóteles, Fís. A4, 187 a 20. 
Se suele hablar del "oscuro Heráclito"; sin embargo, pocos filósofos con un sistema más integrado: cada término tiene en él una cabal respuesta en los demás términos. En Heráclito lo existente puede estar representado por tres círculos concéntricos como señala Jaegger: antropológico, cosmológico y teológico, tres círculos integrados. Algunas de las palabras que más se repiten en él son: "Dios", "logos" y "fuego"; una detención en ellas nos convencen que casi encierran la misma semántica. Estas tres palabras son, por cierto, metáforas para aprehender lo óntico, y toda metáfora, como decía Ortega y Gasset: "Es como la caña de pescar, no pesca pero ayuda a pescar".

Veamos, aunque brevemente, como los tres términos intentan dibujar la constitución polémica del ser.

A) Dios en Heráclito es un ser omni-sapiente. El ser humano es sapiente solo conoce fragmentos de la verdad, lo que le lleva a confundir a veces los conceptos y juzgar erróneamente. Dios es el ser "de mirada amplia", y por amplia cierta y justa, no por ello un ser sin complejidad, de aparente contradicción, pues es la bondad y a la par la justicia, tal como expresa el fragmento B 67 .

B) El "logos". El "logos", "aun siendo claro, siempre se muestra a los hombres incapaces de comprenderlo" (Fr.B1) -nuevamente el choque de contradicciones-; aquí, desde una clave cristiana, estamos tocando la noción de misterio (Efesios 3). La discusión entre los exégetas de Heráclito sobre la palabra "logos, parte de entenderla filosóficamente y no teológicamente. Heráclito, quedó dicho, es también un teólogo, no niega el saber del hombre, "debemos ser sabios" (Fr. B 116), pero sobre todo creyentes en el misterio filosófico y sus aparentes contradicciones. Logos es tal vez, la palabra fundamental del pensamiento griego; sin embargo, como ha estudiado detenidamente Fattal ${ }^{17}$ no siempre ha tenido las mismas acepciones. Ciertamente la raíz es leg donde se halla un valor racional, distributivo y declarativo, pero solo con Heráclito se empieza a reflexionar sobre el logos y sus aspectos oscuros.

Se ha reiterado que Heráclito es el "devenir", frente a Parménides que ama las "permanencias". Toda esquematización nos puede llevar a error, uno

17 Fattal, Michel, (2001). Logos, pensé et verité dans la philosophie grecque. Ed.

L'Hasmattan. París. 
y otro amaron el "logos", que es permanencia y devenir, verdad y acción. Olof Gigon $^{18}$ ha señalado que Heráclito es un ético que pide vivir con la difícil verdad. El "logos" en Heráclito es como la ley, estática y operativa. Ahora bien, la ley "estática" heracliana, ley del cosmos, implica una sabia movilidad, pues de ella surge la armonía a la que el hombre debe plegarse. Ley universal del cosmos y ley personal son dos ruedas que deben girar a la par. Este "arjé" o "principio" de estaticidad y movilidad, este pólemos se significa en el fuego, uno y móvil. ¿Cómo se puede comprender esta aparente contradicción heracliana,

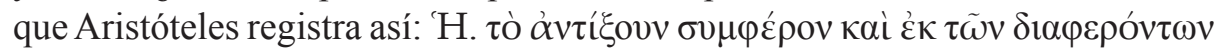

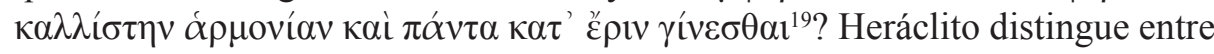
hombres "despiertos" y hombres "dormidos", no obstante, los "dormidos" por ser igualmente portadores de la inteligencia (Fragmento B113) pueden abrir los ojos y entender estos fundamentos del "cosmos", que es entender los fundamentos del hombre y de su accionar en la Política, así, con mayúscula.

Heráclito dice en el Fragmento 123 que "la naturaleza ama ocultarse", así es el logos: en cuánto verdad tiene velo, pero también ama quitarse el velo (aletheía, verdad). Al logos se llega mediante la fe no la razón, si el logos es Uno y Todo, se trata del inteligible puro, que es inabarcable: en cuanto está en nosotros "fulgura", en cuanto es en sí, se nos hace "noche".

C) Fuego: Esta fulguración debe entenderse igualmente como pólemos

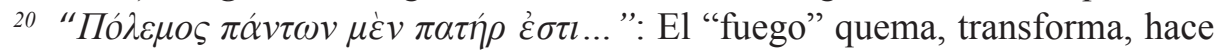
sufrir, pero también purifica ${ }^{21}$. Es agente de destrucción y renovación, como señala René Guénon en "Las dualidades cósmicas" 22 .

18 Gigón, O. (1989).Orígenes de la filosofia griega, de Hesiodo a Parménides. Gredos, Madrid.

19 (DK B 8) Aristóteles, Eth. Nic., IX, 2, $1155 \mathrm{~b} 14$.

20 (DK B 53) Hipólito, Refut., IX, 9.

21 Aguilera, Sebastián. (2014) “Dios, Logos y Fuego en Heráclito”, en Byzantion Nea Hellas, 33, 2014.

22 Este estudio fue escrito en 1921 para la Revue de Philosophie donde no llegó a aparecer, siendo publicado finalmente en Etudes Traditionnelles (nos 429 a 431, Janvier-Juin 1972) por M. Vâlsan, gracias a la amabilidad del hijo mayor del autor. 
En el caso de Anaxímenes, bastará esta cita suficientemente explícita:

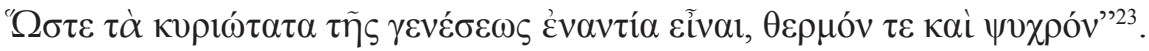

Parménides se excluye de la guerra de los contrarios, pues prescinde de las características que diferencian los seres y que a los demás presocráticos llevó a explicar el cambio o devenir y su implicancia de guerra.

A la luz de lo señalado podemos entender ya el sentido del pólemos en las teomaquias de la Teogonía de Hesíodo y entre Zeus y Prometeo en el Prometeo encadenado de Esquilo, obra deudora de Hesíodo y del pensamiento presocrático, una lucha de contrarios en favor de la dike o justicia entre los hombres, que llegará con el Prometeo liberado.

\section{2.- La política griega del siglo V: oposición y democracia}

Ya hemos comentado la formación política de Esquilo: cómo su infancia se corresponde con la tiranía de los Pisistrátidas, Hipias e Hiparco; tenía 15 años en el momento en que fue asesinado Hiparco (510), hecho que llevó a la expulsión de Hipias y término de la tiranía; a los 17 años (508) conoció la reforma constitucional de Clístenes camino hacia la democracia y conoció las reformas de Temístocles (487-86). Presenció el estadio conservador de Cimón, la decidida acción de Efialtes hacia la democracia (462-61) y el ascenso de Pericles, corega de su obra cuando en el año 472 representó Los Persas. Por cierto, Esquilo conoció la amenaza persa, el surgimiento del sentimiento de libertad ateniense, es así como participó en la batalla de Maratón $^{24} \mathrm{y}$, seguramente, fue soldado en las batallas de Salamina y Platea, Los Persas es una obra de un autor testigo.

No fue fácil el ascenso ateniense hacia la democracia, el pólemos aquí no fue conceptual como en los presocráticos, sino político. Entendamos que Grecia empezó a construir el derecho sobre el quehacer político, no en abstracto: hasta Platón y Aristóteles, como señala Héctor García Cataldo, no existía

23 (DK 13 A 7) Hipólito, Refutatio, $1,7$.

24 Es conocido el epitafio que el mismo redactó para su tumba: "Esquilo, hijo de Euforión, ateniense, yace aquí, en la tierra de Gela, fértil en trigo, sepultado. Su valor, el bien famoso recinto sagrado de Maratón puede decirlo, y el medo de espesa cabellera lo conoce" 
una reflexión sistemática sobre las instituciones y los métodos del quehacer político. La filosofía política griega llegó más tarde que las reflexiones sobre la naturaleza del derecho y la justicia, de ahí la importancia de estudiar estos aspectos en los presocráticos y la literatura de la época.

La reforma de Solón enfrentó a la aristocracia y el pueblo y puso en marcha una idea de pólemos político que no concluirá hasta Pericles; no existe ciertamente, al menos en forma explícita, una alabanza a situaciones extremas en Solón, pero también hay que leer lo expresado por Aristóteles quién conserva su Constitución: "Siendo de tal naturaleza el ordenamiento de la constitución, y siendo muchos esclavos de unos pocos, el pueblo se levantó contra los notables" y eligió a Solón para que elaborase una Constitución. Solón habla de "la guerra dormida que despierta" 25 . La discordia o pólemos no es mala, lo censurable son las causas que impiden mediante el diálogo, una concordia; pero dentro de toda concordia debe existir, tiene que existir para que sea tal, un disenso. El texto de Solón, citado por Plutarco, es elocuente:

"Al pueblo (démos) le di todo el poder que le hace falta
sin privarlo de honor ni darle demás.
Y de los que tenían poder y por sus riquezas eran admirados,
también me cuidé de que ellos no sufrieran agravio alguno.
Resistí cubriéndolos a ambos con un sólido escudo
y no permití que ninguno de ellos venciera con injusticias".26.

Eran también palabras suyas que la Moira ha puesto riesgo y peligro en todo -pólemos- pues en asuntos importantes, es imposible agradar a todos; en las cosas, habiendo comienzo, a veces, no sabemos cómo terminarán, algo que Solón llamaba "incertidumbre". No es de este momento resolver las responsabilidades humanas o azares de tal incertidumbre. Solo una mente poética intuitiva como la de Solón, fue la que supo resolver sabiamente estos casos; no la de ingenieros, juristas o politólogos, como se dice ahora.

La visión del mundo como necesario pólemos -algo que acusan todas las tragedias de Esquilo - marcó al trágico Esquilo desde la infancia. Su familia pertenecía a una aristocracia rural, a una clase media acomodada; en su casa,

25 Elegía "Eunomía”, verso 19.

26 Plutarco, Solón, XVIII, 4. 
como Eupátridas que eran sus padres, se sentían, comentaban y juzgaban los cambios políticos que estaban sucediendo. José Luis de Miguel llega a decir de Euforión, padre de Esquilo: "Pudo haber ejercido algún tipo de influencia política, por lo menos hasta mediados el siglo $V$ a. $C{ }^{\prime 27}$. Si, además, vemos a Esquilo combatir en Maratón y orgulloso de esta acción política, no cabe duda alguna que su sensibilidad política no era ajena a lo que estaba sucediendo. La familia de Esquilo, no obstante pertenecer a una aristocracia terrateniente, coincidía con otros grupos igualmente aristocráticos favorecedores del cambio. Existe una obra en Esquilo que, aparentemente, quiebra este ideal democrático, Los Siete contra Tebas: una tragedia que pareciera no tener un final feliz, pues mueren los dos hermanos, los hijos de Edipo; pero Tebas, la ciudad, la representante del pueblo y la democracia, sí se salva ${ }^{28}$.

El año 508 a.C. llegó la reforma de Clístenes, no le fue fácil a Clístenes su reforma. Iságoras ganó el arcontado en el 508 a.C. su proyecto, "polémico", fue despojar de la ciudadanía a todos los que la habían recibido de Solón y Pisístrato, a lo que Clístenes se opuso, pero hubo de renunciar y abandonar Atenas. No obstante ello, el intento oligárquico de Iságoras, se pidió popularmente a Clístenes el regreso al poder. Las reformas de Clístenes hicieron que Atenas avanzase, entonces, hacia una democracia más plena.

Esquilo, joven, apasionado, asimiló con fuerza las propuestas de Clístenes; estaba dispuesto para ello por temperamento: hombre de una profunda formación intelectual, intuyó que la historia como oposición de contrarios iba por distintos caminos de aquéllos que la aristocracia tradicional quería; y hombre de gran sensibilidad artística, se dio cuenta que la época arcaica representada en los kouroi y la areté de herencia homérica, estaba dando lugar a otros modelos clásicos y una ética de responsabilidad personal; percibió, así mismo que la visión mítica de Hesíodo (Teogonía), sin negar su fuerza religiosa, era necesario ponerla en la calle, que es lo que hizo Prometeo al entregar el fuego a los hombres. Existen detalles en la vida de Esquilo que acusan este afecto del trágico por el démos: se dice que un día, todavía niño, cuidando los viñedos de su padre, se le apareció el dios Dioniso - el dios

27 Estudio introductorio a la Orestea, Ediciones Akal, 1998, pág.8.

28 La idea es de Enrique Herrera, en Daímon, Revista de Filosofía, 45, año 2008.

En Esquilo el conflicto es entre ideas no entre personas, de ahí, en ocasiones, los desajustes interpretativos. 
popular- invitándole a escribir tragedias ${ }^{29}$; y así lo hizo, con 13 victorias según Vita (13), según Suda 28. El pueblo le reconoció esta contribución a las ideas de los nuevos tiempos al conceder un coro a quien representase alguna de sus obras (Vita 12).

Llegó en tanto la confrontación persa. Un pólemos ahora internacional. ¿Alcanzó consenso en tal situación la dicotomía del alma griega? La historia oficial y "macro" dice que sí; recojo, no obstante, las palabras de Walter Donlan: "No todos los griegos se alegraron de la derrota de los persas. Al parecer, no pocos desde la Acrópolis les hacian señales con un escudo diciéndoles, que Atenas estaba dispuesta a rendirse (...) En Atenas había algunos que ciertamente eran partidarios de los persas, algo que marcó negativamente en el futuro a personajes politicos distinguidos ${ }^{\text {"30 }}$.

En la historia del pólemos político griego después de las Guerras Médicas, que tanto favoreció la identidad helena, apareció la confrontación con Esparta. Las fuentes de esta confrontación se encuentra registrada en Tucídides, Plutarco, Heródoto y Diodoro Sículo, así como en algunas comedias de Aristófanes; la información es más completa para Atenas, menos para Esparta. La confrontación se trasladó luego a la "Liga de Delos". La Caída de Cimón y las reformas de Efialtes, constituirán la última y difícil etapa "polémica" hacia la democracia de Pericles. Si existe una palabra griega que mejor califique el pólemos político griego es, en este contexto, la institución del "ostracismo"31: en esta lucha política fueron conducidos al ostracismo definitiva o temporalmente: Pisístrato, los Alcmeónidas, Hipias, Clístenes, Cleómenes, Temístocles, Cimón, el político Tucídides, entre los de más relieve.

La obra de Efialtes se centró en la reforma del Areópago, institución cada vez menos aristocrática; no obstante balancear la tradicional oposición del Areópago, dejando en sus manos los asuntos de homicidio y religiosos, grupos adictos al "statu quo", asesinaron a Efialtes. Asumió, entonces, Pericles que, como hemos señalado más arriba, fue corega de Los Persas cuando Esquilo en

\section{Pausanias, I,2.}

30 Donlan, W. y Tolbert, J. (2002). La Antigua Grecia. Crítica, Barcelona, pág. 218.

31 "Ostrakon" era un fragmento de cerámica en el que se inscribía popularmente el nombre de la persona destacada, pero impopular, que deseaban fuese exiliada hasta por diez años. 
el año 472 se representó esta obra suya.

Lejos de nosotros pensar que con la democracia de Pericles (495429) el pólemos griego desapareció aunque, ciertamente, se acalló ${ }^{32}$; el tema se trasladó intelectualmente a la oposición entre physis (naturaleza) y nomos (costumbre); se defendía por parte de los antidemócratas que, por naturaleza (physis) no todos los hombres son iguales, la igualdad solo debe ser tenida en cuenta entre "excelentes", pues lo bajo solo genera "lo bajo", algo a lo que se opuso Protágoras de Abdera. El monumento funerario dedicado al líder del movimiento oligárquico, Critias, abundaba en ideas antidemocráticas similares: "Este monumento conmemora -se leía- a los hombres excelentes que, durante un breve tiempo, contuvieron la arrogancia del maldito pueblo de Atenas",33; $\mathrm{y}$, en fin, una figura tan destacada como Isócrates (436-338) -murió víctima de una huelga de hambre- era acérrimo defensor de la monarquía ancestral para Atenas.

Alguien podrá pensar en un Esquilo propenso a la fácil democracia. Nada más ajeno al pensamiento del dramaturgo. Esquilo carga al pueblo con más obligaciones que derechos: impone al pueblo la ética homérica centrada en el areté; el pueblo será en adelante aristocrático, pues la areté no será heredada, sino adquirida, con las obligaciones y riesgos que ella impone como esfuerzo personal; el heroísmo futuro brotará no ya de hazañas míticas como las de Homero, sino de acciones político-sociales, no menos exigentes que aquéllas; la moderación, sophrosýne, será imperativo para todos, y única forma de superar los excesos tanto de la aristocracia conservadora como de la hýbris persa o egipcia ${ }^{34}$; propone Esquilo aceptar que las erinias, como dice

32 Basta recordar el opúsculo anónimo (del 440 ó 427), conocido como "El Viejo Oligarca", cuyas esperanzas en el "demos", son muy pocas. Los atenienses percibían al ver "Antígona" de Sófocles, que la democracia conlleva una irresolución, por quién votar ¿por Creonte o por Antígona?

33 En Josiah Ober: "Conflictos, controversias, y pensamiento político", recogido por Robin Osborne en La Grecia Clásica, Oxford University Press, trad. Gonzalo G. Djembé. Crítica. Barcelona, 2002, pág. 148.

34 Tema de Los Persas como de Las Suplicantes, es precisamente ése, la censura de la hýbris. En el caso de Las Suplicantes, Esquilo defiende la asamblea democrática popular, que interviene y decide cuando Dánao -padre de las suplicantes- pide ayuda para sus hijas. Hay en la tragedia una censura a la impiedad de los egipcios, una defensa de la asamblea popular, y una cesión del poder real ante la decisión de la 
Eurípides, no están fuera de Orestes, sino dentro de él, están dentro de nosotros, que es la conciencia ${ }^{35}$. Esquilo enseña también a los atenienses, que el bien desde el punto de vista pragmático, no siempre triunfa: Etéocles era un hombre lleno de areté, sin embargo, a los ojos de los exitistas, murió, fue un fracasado; finalmente, Esquilo nos enseña que el sufrimiento es escuela de aprendizaje. Entonces, no es fácil ser pueblo, con las virtudes que este nombre conlleva. Si Prometeo, identificado con el pueblo ${ }^{36}$, no hubiese sabido ser héroe de los nuevos tiempos sufriendo como sufrió, soportando la aparente desesperanza como Gandhi o Mandela en nuestros tiempos- aceptando de antemano la voz de Hefesto y Hermes que le decían, todo camino concluyó, no hubiese dado a los hombres tantos dones como les entregó, desde aprender las letras hasta surcar los mares. Prometeo enfrentó hasta a Zeus, pero no como un ateo, porque sabe que Dios es necesario ${ }^{37}$, lo asimila con otro concepto, el que dibujará en Prometeo liberado. Ahora podemos entender la batalla de Maratón y Salamina, dos hechos heroicos, imposibles ante el poderio persa, posibles con la nueva areté popular que asume personalmente Esquilo; esto es lo que pone en escena.

La filosofía política de Esquilo es más sutil. Distingue Esquilo lo que radica en la naturaleza de la fysis y lo que depende de situaciones sociales cambiantes. En su obra trata de combinar ambas situaciones: la naturaleza está animada por un pólemos hacia una dike ${ }^{38}$, esto pertenece a la realidad física permanente, pero los cambios políticos obedecen y son juzgados, de otro modo, según una inteligencia práctica, distinta en cada caso. En Prometeo

Asamblea. El rey de Argos tiene poder, pero no hace uso de él, en favor de la decisión democrática popular.

35 Es el problema de Raskolnikoff en Crimen y Castigo de Dostoievski: el pecado persigue, pero se convierte en virtud, en paz - en Euménides- cuando el tribunal del Areópago dicta sentencia y Orestes la acepta o cuando, como en el caso de Raskolnikoff, la justicia se impone, y la carga de conciencia desaparece.

36 En la enumeración de dones que entregó a los mortales, según su propia confesión, todos son dones populares, de carácter agrícola, artesanal y saberes comunes.

37 Esta afirmación es manifiesta en Esquilo, los hombres pueden hacer mucho, pero no todo; en las obras de Esquilo los hombres luchan denodadamente por la justicia y la paz, pero nada hubiese positivamente sucedido si Atenea no hubiese dado el voto absolutorio en favor de Orestes; en un mundo desacralizado, se puede pensar en contra, pero habría que resolver el por qué los seres humanos buscamos la justicia como "algo sagrado".

38 Dike querida por Dios, tesis de Los Persas. 
encadenado y en la Orestía - la primera obra de inmovilismo y la segunda de claras transformaciones hacia el Areópago, existe una clave ética común: que es política, y a la vez que de valores permanentes, la superación de la hýbris. El pólemos, idea central en el pensamiento griego es precisamente así: de derecho natural y de derecho positivo o político: en virtud de ello, Zeus en Prometeo encadenado, "es" y políticamente cede en pro de una dike, cuyo nombre último se llama democracia ${ }^{39}$.

\section{3.-La arquitectura literaria de "Prometeo encadenado"}

Dos polos estructuran la tragedia: Zeus, un dios nuevo y como nuevo exigente, "tiránico" (v.10), todos hemos sido víctimas alguna vez de estos nuevos tiranos; en el otro polo Prometeo, más democrático. Esta bipolaridad extrema se irá lentamente debilitando en pro de un acercamiento democrático, que no se resolverá en esta tragedia, sino en Prometeo liberado (tragedia de la que solo se conservan fragmentos). Observemos que Zeus no condena a Prometeo al Hades ni al Tártaro, lugares imposibles de salir, sino a una roca, anunciando ya desde los primeros versos la posibilidad de salida. La polaridad de Zeus se encuentra en los versos: 201, 236, 321, 373,762, 782, 941, 974, 988, 990, 1028) y la de Prometeo en los versos 30, 180, 260, 318, 542, 936, 1036.

Actúan como mediadores entre esta bipolaridad: Hefesto, las Oceánidas, el Coro, Ío y Hermes; ellos encarnan el diálogo en Prometeo; la tragedia es un diálogo, una forma de entenderse. Lo viejo y lo nuevo, Zeus y Prometeo, más tarde Erinnias viejas y Euménides nuevas, inician casi desde el principio un camino hacia la armonía o democracia representada en Pericles, que fue un Zeus atenuado o un constructor de un Prometeo liberado. Examinemos estos pasos e intervenciones:

El Coro de las Oceánidas confiesa a Prometeo: “A duras penas persuadi el ánimo del padre para venir a verte”; es el primer paso de descongelamiento del ánimo de Zeus; el dios, en consecuencia, no es inconmovible. El verso 96 señala: "Zeus, el dios nuevo tiene mucho que aprender"; lo confirma otro

39 Aunque la idea de pólemos político, lo hemos centrado principalmente en Atenas, Esparta no lo hacía mal; como leemos en Josiah Ober, artículo citado (o. cit. pág.151): "Esparta, bajo el aspecto de estabilidad, la ciudad estaba en guerra permanentemente consigo misma". 
texto: "No cederá mientras no sacie su encono" (Coro). En consecuencia, se propone la venganza de Zeus como transitoria; no olvidemos que el Coro es el personaje colectivo más importante en Esquilo, el "espectador ideal”, según Nietzsche.

La posibilidad de futura armonía avanza aún más en esta otra confesión de Prometeo al Coro: "Zeus necesitará de mí algún día, no solo dejará su enojo, más aún vendrá a mí y yo no cederé, yo seré el enojado”. Pero resulta que la razón, que para esta movilidad de Zeus exhibe Prometeo, servirá también para él -“el dolor y la vejez, enseñan" (v.981)-:"Será blando cuando sea golpeado por la desdicha, entonces bajará su indomable orgullo y, solicito, cual yo, vendrá a mí amistad y concierto" (Prometeo al Coro). Finalmente, Océano avanza hacia un final de armonía: "Me precio, sí, de que Zeus me otorgará la gracia de alzarte esta pena”.

El descongelamiento de la dura polaridad de Zeus, es evidente. Pero, ¿qué sucede con la actitud, no menos enconada, de Prometeo?

Veamos el proceso en algunos textos: "De voluntad erré, no lo negaré”, dice al Coro de Oceánidas; reconocer el error es el principio de la luz. Las Oceánidas le dirán: "Es una vergüenza que un hombre prudente persevere en su error" (v.1039). Océano aconseja a Prometeo modere entonces su lengua insultante, primer camino para una buena solución: ¿No sabías que el castigo marca la lengua temeraria? Y, ciertamente, Prometeo confiesa al Coro la actitud de deponer esta irresoluta inmovilidad, aunque bajo una condición: "Yo apuraré esta mi suerte hasta tanto que el ánimo de Zeus no aplaque su cólera". Sabemos que Zeus, por los textos anteriores, inició ya tal "aplacamiento".

Para ambos, para Zeus y para Prometeo, la verdadera escuela es la vejez y el dolor: "Maestro es en verdad el infortunio" (Océano a Prometeo). Tal ideario de Esquilo, en clave política, es propuesto a todos los espectadores atenienses en momentos nada fáciles de la vida política de Atenas.

Finalmente, el Coro, hace un salto profético: "De todos modos, tengo buena esperanza, que aún has de ser suelto de estas cadenas, no menos poderoso que Zeus”, es decir, pertenecerás algún día al ámbito dioses olímpicos.

Al llegar a este momento, Esquilo introduce en su tragedia el tema 
de Ío, y segunda parte de la tragedia, con cuyo tema el futuro infortunio de Zeus, por efecto de la maldición de su padre Cronos, será otro impulso de reconciliación; hay versos reveladores:

Cuando sufra ese golpe: aplacará

Su rigurosa cólera; llegaremos

A entendernos y a ser amigos.

Vendrá agobiado

A socorrer mí agobio. (v. 186-92).

El final de la tragedia "Prometeo encadenado" pareciera truncar toda la dinámica propositiva que hemos desarrollado; sin embargo, esta es la invocación final de Prometeo: “'Oh deidad venerada de mi madre! ¡Oh éter que haces girar la luz común para todos, viéndome estáis cuán sin injusticia padezco!" Prometeo pone por testigo de su vida al "Éter y a la Luz", elementos olímpicos.

Sabemos lo que sucede después, un descendiente de Ío, Heracles, liberará a Prometeo. Según Hesíodo, Heracles, hijo de Zeus, mata el águila y libera a Prometeo. Zeus permitirá entonces el culto a Prometeo en Ática y, además, perdonará a Cronos -en el Tártaro- para que la maldición de éste - que alguien destronaría a Zeus- no se cumpla. Zeus sella la armonía con Prometeo y Cronos. Por este camino, Zeus y Prometeo ascienden finalmente a una estatura moral ejemplar; se ha dicho: Prometeo aparecerá entonces en el Olimpo, coronado, transformadas las cadenas en diadema. 


\section{Conclusión}

Esta resolución del pólemos en la tragedia de Prometeo se observa como tesis generalizada en otras obras de Esquilo: Las Erinias serán transformadas en Euménides, en Euménides; la "ley de sangre”, cambia en ley de "venerables varones que administran justicia en el Areópago" ("Orestía”); en Las Suplicantes, es Hipermestra quien quebranta la enemistad (el pólemos) de Egipto frente a Argos, de la que nacerá - según otra tradición que Esquilo sabe aprovechar- una estirpe regia de la que nacerá el libertador de Prometeo; por cierto, otro par de figuras, reducida a armonía es el de Hera e Ío; el castigo a ésta, convertida en vaca y vagando picada por un tábano, desaparece con el nacimiento de Heracles, el libertador de Prometeo. La hybris se transformará, así, en sofrosýne, la adikía en dike, el pólemos en diálogos, las tradicionales luchas políticas desde Solón hasta Pericles, en democracia. La lección política de Esquilo es manifiesta ${ }^{40}$.

40 El énfasis en el carácter evolutivo de Zeus, de un dios, del que "es", pareciera molestar a algunos intérprete; pero, lo señaló Adrados en su día: "Al comparar la divinidad en Esquilo con la de Heráclito, vemos que la de éste es síntesis simultánea, sin evolución, de dos contrarios". Dios, justamente por ser el "ser", es a la vez tiempo y eternidad, justicia y bondad, en términos cristianos: Yavé del Sinaí y el Dios del amor en la Cruz. Tal misterio, sin problematizarlo, estaba ya planteado entre los griegos. 


\section{REFERENCIAS BIBLIOGRÁFICAS}

ALBIN LESKY.(1968), Historia de la literatura griega. Mdrid: Gredos.

DONLAN, W. ET AL. (2010) La antigua Grecia. Barcelona: Crítica.

ESQUILO, (1998), Tragedias. Buenos Aires: Losada.

FATTAL, MICHEL (2001). Logos, pensé et verité dans la philosophie grecque.

París: Ed. L'Hasmattan.

GARIBAY. ANGEL MA. Mitología Griega. Buenos Aires: Edit. Porrúa.

GIGÓN, O. (1989). Orígenes de la filosofía griega, de Hesiodo a Parménides. Madrid: Gredos.

GARCÍA A. CÉSAR. Estudios publicados en Byzantion Nea Hellás sobre "La idea de justicia en la tragedia griega", "Un estudio sobre el género en la tragedia griega", "La psicología de Clitemnestra" y otros estudios sobre Sófocles.

GRIFFERO, MARÍA CELINA, (1977), "Introducción a la obra de Esquilo" en Las danaides. Buenos Aires: Editorial Albatros.

GRIMAL, PIERRE, (2004), Diccionario de mitos griegos. Buenos Aires: Fondo de Cultura Económica.

HESÍODO, (1995), Teogonía. Barcelona: Editorial Planeta-De Agostini, S.A. HESÍODO (1995), Los trabajos y los días. Barcelona: Editorial Planeta-De Agostini, S. A.

HERRERA, ENRIQUE (2008) "La idea de justicia en Esquilo", en Revista de Filosofía, N.45

JAEGER, W (1982). Alabanza de la Ley: Los orígenes de la filosofía del derecho y los griegos (Trad. A. Truyol y Serra). Madrid: Centro de Estudios Constitucionales.

JOSÉ LUIS JOVER, (1998) Introducción a la “Orestea”. Madrid: Akal.

KIRK, GEOFFREY ET AL. (2015). Los filósofos presocráticos. Madrid: Editorial Gredos.

LÓPEZ, AGUSTÍN. “Zeus-Deu.Madrid: Rialp.

MIRALLES, CARLOS (1968) Tragedia y Política en Esquilo. Barcelona: Ariel. MIRALLES., CARLOS (1949 Evolución del pensamiento político griego, publicado en Eschilo e Atene, Turín.

MURRAY, GILBERT, (1943), Esquilo, el creador de la tragedia. Buenos Aires: Espasa Calpe-Austral.

NIETZSCHE, FIEDRICH, (2003), El origen de la tragedia. Buenos Aires: Ediciones Andrómeda.

OSBORNE, R. (2002). La Grecia Clásica. Oxford, University Press, 2000. Trad. Gonzalo Djembé. Barcelona: Crítica. 
RODRÍGUEZ ADRADOS, F. (1966) “Ilustración y política en la Grecia Clásica”. Madrid: Revista de Occidente.

SECHAN, LOIS, (1960), El mito de Prometeo. Buenos Aires: Editorial Eudeba. W. F. OTTO. (2003) Los dioses de Grecia. Madrid: Editorial Siruela. Madrid. VERNANT, JEAN - PIERRE. (1973) Mito y pensamiento en la Grecia antigua. Barcelona: Ariel. 